\title{
THE FACTORS THAT DETERMINE REPRODUCTIVE HEALTH CHARACTERISTICS OF ADOLESCENTS IN SERBIA
}

Gordana Djordjevic ${ }^{1}$, Snezana Radovanovic ${ }^{2}$, Nela Djonovic ${ }^{3}$, Svetlana Radevic ${ }^{4}$, Dragan Vasiljevic ${ }^{3}$, Natasa Mihailovic ${ }^{5}$ ${ }^{1}$ Department of Epidemiology, Faculty of Medical Sciences, University of Kragujevac and Institute for Public Health, Kragujevac, Serbia ${ }^{2}$ Department of Social Medicine, Faculty of Medical Sciences, University of Kragujevac and Institute for Public Health, Kragujevac, Serbia ${ }^{3}$ Department of Hygiene, Faculty of Medical Sciences and Institute for Public Health, Kragujevac, Serbia ${ }^{4}$ Department of Social Medicine, Faculty of Medical Sciences, University of Kragujevac, Serbia ${ }^{5}$ Center for Informatics and Biostatistics, Institute for Public Health, Kragujevac, Serbia

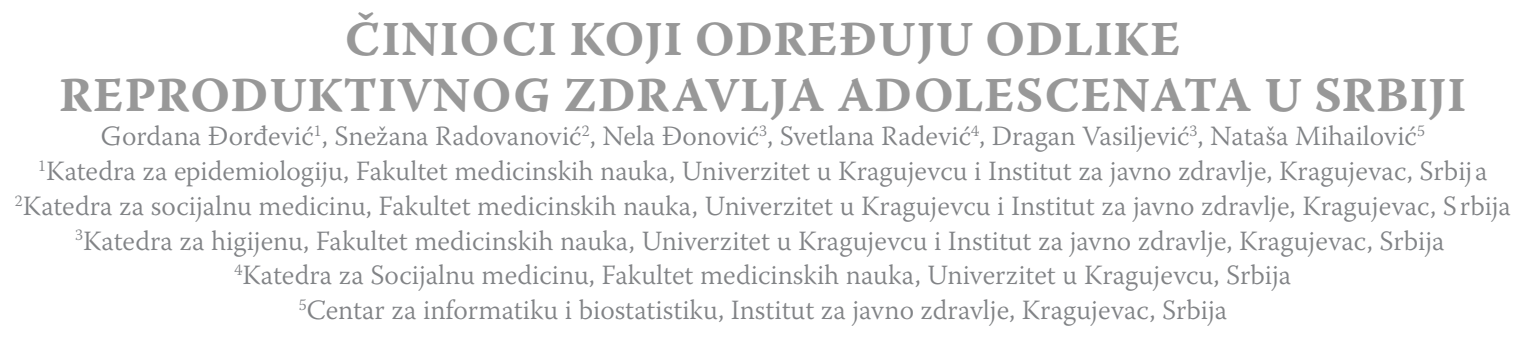

Received / Primljen: 29. 05. 2017.

Accepted / Prihvaćen: 06. 06. 2017.

\begin{abstract}
The aim of the work is to assess vulnerability degree of reproductive health in adolescent population in Serbia by analyzing their sexual behavior. The paper is based on data from a National health survey of the population in Serbia in 2013 (without Kosovo and Metohija region), conducted by the Ministry of Health of the Republic of Serbia. For the purposes of this study, the data used are referred to households and population of age 15 and over, so that the final number for analysis is a sample of 1722 respondents aged $15-24$. The study included demographic characteristics of respondents (age, gender, settlement type, region) and the characteristics of reproductive health: sexual behavior, use of contraceptive protection, knowledge and attitudes towards HIV, protection of reproductive health. $X^{2}$ test was applied for testing differences in frequency of categorical variables. All results with a probability that equals to or is less than $5 \%(p \leq 0.05)$ are considered statistically significant. Among the respondents, there were more than half (53.5\%) of sexually active adolescents. The highest percentage of them-16.6\% responded that they had first sexual intercourse at the age of 17. 53.4\% of adolescents had sexual intercourse with one partner, $26.4 \%$ of respondents had sexual intercourse with two or more partners. The most commonly used contraceptive method was interrupted intercourse (coitus interruptus) with $34.7 \%$ of respondents.
\end{abstract}

Key words: reproductive health, adolescents, Serbia, National Health Research

\section{SAŽETAK}

Cilj rada je da se proceni stepen ugroženosti reproduktivnog zdravlja adolescentske populacije u Srbiji analizom njihovog seksualnog ponašanja. Rad se zasniva na podacima iz nacionalnog istraživanja zdravlja stanovništva Srbije u 2013. (bez podataka za Kosovo i Metohiju), koje je sprovelo Ministarstvo zdravlja Republike Srbije. Za potrebe ovog istraživanja, korišćeni su podaci o domaćinstvima i stanovništvu starosti 15 i više godina, tako da je u konačni uzorak za analizu ušlo 1722 ispitanika starosti 15 do 24 godine. U istraživanju su korišćene demografske karakteristike ispitanika (starost, pol, tip naselja, region) i obeležja reproduktivnog zdravlja: seksualno ponašanje, korišćenje kontraceptivne zaštite, znanje i stavovi o HIV-u, zaštita reproduktivnog zdravlja. X2 test je primenjen za testiranje razlika u učestalosti kategorijskih varijabli. Svi rezultati sa verovatnoćom koja je jednaka ili manja od 5\% ( $p \leq 0,05)$ su smatrane statistički značajnim. Među ispitanicama je bilo više od polovine (53,5\%) seksualno aktivnih adolescenata. Najveći procenat njih 16,6\% se izjasnio da je prvi put stupio u seksualne odnose sa 17 godina. Seksualni odnos sa jednim partnerom upražnjavalo je $53,4 \%$ adolescenata, a sa dva ili više partnera $26,4 \%$ ispitanika našeg istraživanja. Najčešće korišćeno kontraceptivno sredstvo je bio prekinut snošaj 34,7\%.

Ključne reči: reproduktivno zdravlje, adolescenti, Srbija, Nacionalno istraživanje zdravlja sciendo

UDK: 613.88-053.6(497.11)"2013"

Ser J Exp Clin Res 2019; 20 (2): 23-26 DOI: 10.1515/SJECR-2017-0028
Corresponding author: Snežana Radovanović Department of Social Medicine, Faculty of Medical Sciences,
University of Kragujevac, Serbia; Svetozara Markovica 69, 34000 Kragujevac, Serbia fone: +381343068 00 fax: +381 343313 44; 


\section{INTRODUCTION}

One of the modern societies features is an increase in sexual activity among young people. This is manifested by the growing proportion of adolescents sexually active, by a growing number of those who had the first sexual experience in the period of early adolescence and lowering the average age when the first sexual intercourse is realized. Sexual activity is followed by new health problems. This can result in unwanted pregnancy and the occurrence of diseases that are transmitted through sexual contact. Risk for the damage of reproductive health depends on the adopted model of sexual behavior, as well as on many other determinants of physiological characteristics and health habits of an individual, and it also depends on number of factors related to socio-cultural environment. Reproductive health of young people in the age of adolescence is particularly affected which is explained by the unfinished processes of their physical and psychosocial maturation. Young people are susceptible to various influences of immediate and wider social environment and the environment affects -to a greater or lesser extent their knowledge, attitudes and behavior in the areas of sexuality and reproduction (1).

\section{THE AIM OF STUDY}

The aim of the paper is to assess the vulnerability degree of adolescent reproductive health in Serbia by analyzing their sexual behavior.

\section{METHOD}

\section{Data source and type of study}

The paper is based on data from a national health survey of the population of Serbia in 2013 (no data for Kosovo and Metohia region). This is the third national survey of health of the population, conducted by the Ministry of Health of the Republic of Serbia. The survey was conducted in accordance with the methodology and instruments of the European Health Survey - Second Wave (EHIS-wave 2). We used a nationally representative random sample, stratified two-stage sample with a known probability of selection of sample units at every stage of sampling. The sample was selected so, as to provide a statistically reliable estimate of the large number of indicators that indicate the health of the population at the national level. The mechanisms that have been used to obtain a random sample of households and respondents, represent a combination of the two sampling techniques: stratification and multi-stage sampling. For the purposes of this study, the data on households and population age 15 and over were used, so that the final sample for analysis entered 1722 respondents aged 15 to 24 .

\section{Variables}

Demographic characteristics (age, gender, type of settlement, region) were used as independent variables. Reproductive health is described and analyzed through the following characteristics: sexual behavior (sexual relations with a steady partner and someone who is not, the use of contraceptive protection, ( opinion on condom use, used contraceptive type), reproductive health protection (antenatal age at the first visit to a gynecologist, gynecologist visits in the last 12 months, the reason for the visit, abortions ).

\section{Statistical data processing}

All data of interest are presented and analyzed by adequate mathematical-statistical methods appropriate for the data type. $X^{2}$ test was applied to test the difference in the frequency of categorical variables. All results with the

Table 1. Sexual behavior adolescents in Serbia in relation to sociodemographic characteristics

\begin{tabular}{|c|c|c|c|c|c|c|c|c|}
\hline Variables & $\begin{array}{c}\text { Sexual } \\
\text { intercourse } \\
\text { with one } \\
\text { partner }(\%)\end{array}$ & $\mathrm{p}$ & $\begin{array}{c}\text { Sexual } \\
\text { contact } \\
\text { with two or } \\
\text { more part- } \\
\text { ners }(\%)\end{array}$ & $\mathrm{p}$ & $\begin{array}{l}\text { Condom } \\
\text { used during } \\
\text { the last } \\
\text { sexual con- } \\
\text { tact (\%) }\end{array}$ & $\mathrm{p}$ & $\begin{array}{l}\text { Used con- } \\
\text { dom with } \\
\text { occasional } \\
\text { partners } \\
(\%)\end{array}$ & $\mathrm{p}$ \\
\hline \multicolumn{9}{|l|}{ Sex } \\
\hline $\begin{array}{l}\text { Male } \\
\text { Female }\end{array}$ & $\begin{array}{l}52.9 \\
47.1\end{array}$ & $\mathrm{p}<0.001$ & $\begin{array}{l}77.2 \\
22.8\end{array}$ & $\mathrm{p}<0.001$ & $\begin{array}{l}57.1 \\
42.9\end{array}$ & $\mathrm{p}<0.05$ & $\begin{array}{l}69.9 \\
30.1\end{array}$ & $\mathrm{p}<0.001$ \\
\hline \multicolumn{9}{|l|}{ Settlement type } \\
\hline $\begin{array}{l}\text { Urban setting } \\
\text { Ruralna setting }\end{array}$ & $\begin{array}{l}58.1 \\
41.9\end{array}$ & $\mathrm{p}<0.05$ & $\begin{array}{l}57 \\
43\end{array}$ & $\mathrm{p}<0.05$ & $\begin{array}{l}63 \\
37\end{array}$ & $\mathrm{p}<0.05$ & $\begin{array}{l}58.6 \\
41.4\end{array}$ & $\mathrm{p}>0.05$ \\
\hline \multicolumn{9}{|l|}{ Region } \\
\hline Belgrade & 25.4 & \multirow{3}{*}{$\mathrm{p}<0.001$} & 21.5 & \multirow{3}{*}{$\mathrm{p}<0.001$} & 25.8 & \multirow{3}{*}{$\mathrm{p}<0.001$} & 22.6 & \multirow{3}{*}{$\mathrm{p}<0.001$} \\
\hline $\begin{array}{l}\text { Vojvodina } \\
\text { Shumadia and Western Serbia }\end{array}$ & $\begin{array}{l}22.9 \\
25.9\end{array}$ & & $\begin{array}{l}31.1 \\
24.4\end{array}$ & & $\begin{array}{l}26.4 \\
21.5\end{array}$ & & $\begin{array}{l}26.3 \\
22.9\end{array}$ & \\
\hline South and Eastern Serbia & 25.8 & & 23 & & 26.4 & & 28.2 & \\
\hline
\end{tabular}


probability that is equal to, or less than $5 \%$ ( $\mathrm{p} \leq 0.05$ ) were considered statistically significant. Statistical analysis was performed using a commercial, standard software package SPSS, version 19.0. (The Statistical Package for Social Sciences software (SPSS Inc., version 19.0, Chicago, IL).

\section{RESULTS}

From a total of 1722 respondents aged 15-24 (average age $19 \pm 2.1$ years) $49 \%$ of boys and $51 \%$ girls were interviewed. $55.5 \%$ of the surveyed adolescents were from urban areas. 30\% of adolescent respondents were from Sumadia and West Serbia regions.

The survey results show that there are more than half (53.5\%) sexually active adolescents, boys (52.9\%) more often than girls $(47.1 \%),(\mathrm{p}<0.001)$. The highest percentage $16.6 \%$ of them confirmed that they had their first sexual experience at the age of 17 years old, girls (53.4\%) more often than boys $(46.6 \%)$, the difference was statistically significant $(\mathrm{p}<0.05)$. In the last 12 months in relation to the survey time $73.2 \%$ of adolescents had sexual intercourse. Sexual intercourse with one partner was with $53.4 \%$ of adolescents, girls more often $(\mathrm{p}<0.05)$ and adolescents from the South and East Serbia (27.8\%) $(\mathrm{p}<0.05)$. $26.4 \%$ respondents from our survey had sexual contact with two or more partners, slightly more boys $(67,4 \%)$ $(\mathrm{p}<0.05)$ and adolescents from Sumadia and West Serbia $(35.4 \%)(p<0.05) .2 .9 \%$ of respondents (male and female alike) declared sexual relations with a person of the same sex. Young men more often than girls ( $77.2 \%$ vs. $22.8 \%)$ had sexual intercourses with a periodic partner in the last 12 months in in relation to the survey time $(\mathrm{p}<0.05)$. During the last sexual contact, a condom was used by $48.5 \%$ of adolescents, more frequently young men $57.1 \%$ compared to $42.9 \%$ of women $(\mathrm{p}<0.05)$. Also, the practice was more often with adolescents in urban areas $63 \%$ and those originated from the South and East Serbia regions (26.4\%) and Belgrade $(26.4 \%)(\mathrm{p}<0.05)$. Only $26.4 \%$ of respondents used condom with occasional partners- more frequently boys $77.2 \%$ than girls $22.8 \%(\mathrm{p}<0.05)$. The most commonly used contraceptive was interrupted intercourse (coitus interruptus) $34.7 \%$. Next contraceptive according to frequency was male condom in $31.9 \%$, infertile days $16.7 \%$ and a day after pill $13.9 \%$. There is a statistically significant difference in contraceptive types used among adolescents from different regions of Serbia, as well as in respect of whether the respondents originate from an urban or rural environment. Interrupted intercourse (coitus interruptus) was the most common form of contraception among adolescents from Sumadia and West Serbia $48.3 \%$. Male condom as the most common form of contraception was used by adolescents from the South and East Serbia $28.4 \%$, while a contraceptive pill was used by adolescents from Vojvodina Region $31.3 \%$ and $31.3 \%$ of Belgrade. Among adolescents from rural areas the most frequently used contraceptive was infertile days method of $55.6 \%$ respondents, while the other methods of birth control were more common among adolescents originating from urban areas $(\mathrm{p}<0.05)$.

\section{DISCUSSION}

In adolescence period young people assume new roles and responsibilities and proper sexual behavior is of vital importance. Risky sexual behavior in adolescence could have serious consequences for health in later life. Risk sexual behavior practice adopted during adolescence can often continue throughout adulthood (2). The national research examining sexual behavior among students showed that more than a quarter of adolescents had sexual intercourse, more often young men. About $25 \%$ of them had not used a condom during their last sexual intercourse. Unprotected sexual contacts were more common in adolescents who used psychoactive substances. The adolescents given guidelines on pregnancy prevention and sexually transmitted infections rarely manifested risky sexual behavior (3). In our study, more than half of the adolescents were sexually active, during which they did not use a condom, while $26.4 \%$ of adolescents had sexual contact with two or more partners. Other studies also noted risky sexual behavior of young people, such as a rare use of condoms and multiple partners (2). Also, many studies have shown that the level of risky sexual behavior among young people is different in comparison to the sex, race and ethnicity. A survey of African American students showed that $46.7 \%$ of them ever had sexual intercourse, that $37 \%$ of sexually active students did not use a condom during last sexual intercourse. It was found that the black race students tend to have sexual intercourse more often, had greater number of sexual partners, as well as they more often used condoms during last sexual contact, as compared to the white students. It was also found that there was no difference related to gender (4). Many teens believe that risky sexual behavior increases their chances of getting infected by HIV and sexually transmitted diseases, but nevertheless the results show that even $39 \%$ of sexually active adolescents do not use a condom during the last sexual intercourse, that more than $10 \%$ of girls aged 15-19 replied that they had multiple partners and the short time intervals between having a sexual contact with two different partners (5). Such risky sexual behavior increases the risk of HIV, sexually transmitted diseases and unwanted pregnancies $(6,7)$. Among teens, nearly $90 \%$ of heterosexually acquired HIV cases are in girls (8), and among the estimated 19 million cases of sexually transmitted infections that occur each year in the United States, girls aged 15-19 have the highest rates of gonorrhea and chlamydia compared to young men of the same age (9). It was also observed that adolescents originating from poorer urban areas start sexual activity at an earlier age (10). Sexually transmitted infections are serious public health problem worldwide, particularly af- 
fecting young people, this is confirmed by the data - 70\% of patients with sexually transmitted infections are aged between 15 and 24 years (3). Reducing risky sexual behavior and sexual education that provides correct information about reproductive health protection can reduce the incidence of sexually transmitted infections as well as to reduce the number of unplanned pregnancies among adolescents (12).

\section{CONCLUSION}

It can be concluded, based on the survey results, that the reproductive health of adolescents in Serbia is threatened to a significant degree. The surveyed respondents are observed with high degree of irresponsibility in sexual behavior. It is essential to inform and educate young people about reproductive health in order to prevent numerous unwanted consequences of ignorance and risk behavior. It is also important to choose the right method to pass important information to young people, in particular to inform the marginalized and socially disadvantaged young people. Cooperation between governmental and non-governmental organizations is necessary in order to improve reproductive health as well as multiple efforts of the community and society in whole.

\section{Conflict of Interest}

Authors declare no conflict of interest.

\section{REFERENCES}

1. Sedlecki K. Ponašanje i stavovi adolescenata relevantni za reproduktivno zdravlje, ctanovništvo 2001; 39:91-117.

2. Dick B, Ferguson BJ. Health for the world's adolescents: a second chance in the second decade. J Adolesc Health. 2015;56(1):3-6.
3. Malta DC, do Prado RR, Caribe SS, da Silva MM, de Andreazzi MA, da Silva Júnior JB, Minayo MC. Factors associated with injuries in adolescents, from the $\mathrm{Na}$ tional Adolescent School-based Health Survey (PeNSE 2012). Rev Bras Epidemiol. 2014;17 (1):183-202.

4. Grunbaum JA, Kann L, Kinchen S, Ross J, Hawkins J, Lowry R, Harris WA, McManus T, Chyen D, Collins J. Youth risk behavior surveillance--United States, 2003. MMWR Surveill Summ. 2004;53(2):1-96.

5. Eaton DK, Kann L, Kinchen S, et al. Youth risk behavior surveillance - United States, 2009. MMWR Surveillance Summaries. 2010;59(5):1-142.

6. Mbalinda SN, Kiwanuka N, Eriksson LE, Wanyenze RK, Kaye DK. Correlates of ever had sex among perinatally HIV-infected adolescents in Uganda. Reprod Health. 2015;12:96.

7. Centers for Disease Control and Prevention. HIV/ AIDS Surveillance Report, 2004. Atlanta, GA: US Department of Health and Human Services, Centers for Disease Control and Prevention; 2005.

8. Centers for Disease Control and Prevention. HIV/AIDS surveillance in adolescents and young adults, slide 8. Atlanta, GA: US Department of Health and Human Services, Centers for Disease Control and Prevention; 2009.

9. Centers for Disease Control and Prevention. 2006 Disease Profile. Atlanta, GA: National Center for HIV/ AIDS, Viral Hepatitis, STD, and TB Prevention; 2008.

10. Siebold C. Factors influencing young women's sexual and reproductive health. Contemp Nurse. 2011;37(2):124-136.

11. Bogani G, Cromi A, Serati M, Monti Z, Apolloni C, Nardelli F, Di Naro E,Ghezzi F. Impact of school-based educational programs on sexual behaviors among adolescents in northern Italy. J Sex Marital Ther. 2015;41(2):121-5.

12. Ismail S, Shajahan A, Sathyanarayana Rao TS, Wylie K. Adolescent sex education in India: Current perspectives. Indian J Psychiatry. 2015;57(4):333-7. 